\title{
Peran Kecenderungan Berpikir Tertutup dan Kecenderungan Kebersetujuan pada Potensi Perilaku Radikal Mahasiswa
}

\author{
Nur Amalia Hamida, Fathul Lubabin Nuqul \\ Program Studi Psikologi, Fakultas Psikologi, Universitas Islam Negeri Maulana Malik Ibrahim, \\ Malang
}

\begin{abstract}
Abstrak. Penelitian ini bertujuan untuk mengetahui tingkat kecenderungan berpikir tertutup dan potensi radikalisme pada mahasiswa, serta menguji bagaimana pengaruh kecenderungan berpikir tertutup dan kecenderungan kebersetujuan terhadap potensi radikalisme. Penelitian ini menggunakan pendekatan kuantitatif dengan jumlah subjek sebanyak 314 orang yang didapatkan menggunakan teknik random sampling. Pengambilan data menggunakan tiga skala, yaitu Short Version Need for Closure Scale (Roets \& Vein Heil, 2007), Big Five Inventory Scale (Jhon \& Srivastava, 1999), dan Disposition Violent Extrimism Scale (Davydov, 2017). Analisis data dalam penelitian ini menggunakan analisis data deskriptif dan regresi linier berganda. Hasil penelitian ini menunjukkan bahwa terdapat pengaruh kecenderungan berpikir tertutup dan kecenderungan kebersetujuan terhadap potensi radikalisme pada mahasiswa dengan signifikansi $.000(p<.01)$. Nilai koefisien determinasi adalah .106 yang menunjukkan bahwa kecenderungan berpikir tertutup dan kecenderungan kebersetujuan berpengaruh $10.6 \%$ terhadap potensi radikalisme mahasiswa.
\end{abstract}

Kata Kunci: kecenderungan berpikir tertutup, kecenderungan kebersetujuan, radikalisme

\section{The Role of Need for Closure and Radical Behavior among Students}

Abstract. This study aimed at determining the impact of need for closure, agreeableness, and the influence of the potential of radicalism to the students. This study used a quantitative approach with 314 subjects obtained using random sampling techniques. Retrieval of data using three scales, Short Version Need for Closure Scale (Roats \& Van Heil, 2011), Big Five Inventory Scale (John \& Srivastava, 1999)and Dispotition Violent Extrimism Scale (Davydov, 2017b). Data collected in this study was then analyzed using descriptive method and multiple linear regression. The findings show that there is a need for closure and agreeableness influence on the potential of radicalism to the students. The results of the analysis indicated the need for closure and agreeableness affect the potential for radicalism to the students with a significance $.000(p<.01)$. Coefficient of determination is .106 which shows thati simultaneously the two independent variables affect the potential radicalism by $10.6 \%$.

Keywords: agreeableness, need for closure, radicalism

Korespondensi: Nur Amalia Hamida. Email: amalianur150@gmail.com 
Radikalisme menjadi salah satu muara dari persoalan-persoalan bangsa, negara, dan masyarakat yang harus ditemukan solusinya (Satriawan \& Lailam, 2019). Hal ini dikarenakan aksi-aksi radikalisme menimbulkan kerugian yang besar bagi negara (Prior, 2016). Solusi untuk mengatasi masalah tersebut menjadi tugas yang belum diselesaikan (Hammad, 2018). Radikalisme merupakan lahan yang baik untuk penanaman bibit terorisme (Hendropriyono, 2009). Badan Nasional Penanganan Terorisme (BNPT) (2012), menyebutkan bahwa radikalisme merupakan bibit dari terorisme, suatu sikap yang bersifat revolusioner dan menginginkan perubahan drastis yang ditempuh dengan upaya-upaya kekerasan. Radikalisme dianggap sebagai permasalahan kompleks, sehingga perlu dikaji dari berbagai disiplin ilmu, baik politik, sosiologi, komunikasi, hukum, dan psikologi untuk menemukan solusi terhadap masalah-masalah radikalisme (Muluk, 2016).

Berbagai aksi peledakan bom merupakan bagian dari sederet aksi radikalisme di Indonesia. Pada tanggal $13 \mathrm{Mei}$ 2018 terjadi pengeboman di Gereja Katolik Santa Maria Tak Bercela yang menewaskan satu orang jemaat dan 13 orang luka-luka yang dilakukan oleh dua orang bersaudara berusia belasan. Pelaku pengeboman merupakan anggota Ansharut Daulah cabang Islamic State of Iraq and Syria (ISIS) di Asia Tenggara (Jamaluddin et al., 2018). Peristiwa pengeboman sebelumnya terjadi pada tanggal
14 Januari 2016 di Sarinah, Jakarta Pusat. Insiden tersebut menewaskan empat orang sipil dan 24 lainnya mengalami luka-luka. Institute for Defence Studies and Analysis (IFDSA) menyebutkan bahwa pelaku merupakan teroris yang telah berbaiat dengan ISIS (Widhana, 2019).

Survei yang dilakukan Wahid Institute pada tahun 2017 menunjukkan bahwa 11 juta penduduk Indonesia bersedia melakukan aksi radikalisme. Sebesar $0.4 \%$ atau sekitar satu juta penduduk Indonesia pernah melakukan aksi radikalisme dan $7.7 \%$ atau 20 juta penduduk Indonesia bertindak radikal jika memungkinkan (Putra, 2017). Lebih khusus lagi, BNPT (2012) menyebutkan bahwa mahasiswa menjadi target penyebaran ideologi radikal dengan persentase sebesar 20.3\%. Selain itu, BNPT menegaskan sasaran perekrutan aksi radikalisme adalah penduduk dengan rentang usia 18 hingga 13 tahun. Hal ini dikuatkan dengan survei yang dilakukan Pusat Pengkajian Islam dan Masyarakat Universitas Islam Negeri Jakarta pada tahun 2017 yang menunjukkan bahwa pelajar dan mahasiswa yang setuju dengan opini radikal sebanyak 58\%. Mahasiswa menjadi pelaku aksi radikalisme bukan merupakan fenomena yang baru (PPIM UIN Jakarta, 2017).

Survei yang dilakukan oleh kepolisian menunjukkan bahwa 23.4\% mahasiswa di Indonesia telah terpapar radikalisme. Hal ini disampaikan oleh Menteri Pertahanan Ryamizard Ryacudu bahwa 23.4\% mahasiswa 
setuju dengan jihad dan memperjuangkan berdirinya negara Islam. Kampus-kampus Islam masih menjadi sasaran ideologi radikal. Hal ini dibuktikan dengan ditangkapnya jaringan PF pada tahun 2011 atas perilaku teror yang ia lakukan kepada beberapa tokoh dengan mengirimkan paket berisi bom buku (Hammad, 2018). Selain PF, 22 orang lainnya yang diduga sebagai jaringan PF ikut ditangkap polisi. Tiga di antaranya merupakan mahasiswa dan alumni Universitas Islam Negeri Syarif Hidayatullah Jakarta (Saifuddin., 2011). Berdasarkan data tersebut, mahasiswa merupakan salah satu kelompok yang rentan terpapar ideologi radikalisme.

Ada perbedaan terminologi antara radikalisme dan terorisme. Kamus Besar Bahasa Indonesia (KBBI) mendefinisikan radikalisme sebagai paham atau aliran yang keras dalam politik, paham atau aliran yang menginginkan perubahan atau pembaharuan sosial dan politik dengan cara kekerasan atau drastis, atau sikap ekstrem dalam aliran politik. Lebih lanjut, Schmid (2013) menyebutkan bahwa radikalisme dapat mencakup penggunaan tekanan dan paksaan (tanpa kekerasan), berbagai bentuk kekerasan politik selain terorisme, atau tindakan ekstremisme keras dalam bentuk terorisme dan kejahatan perang. Radikalisme terbagi menjadi dua, yaitu radikalisasi ideologis dan radikalisasi perilaku. Radikalisasi ideologis menggambarkan proses kognitif murni individu yang mengarah pada pengesahan ide-ide radikal, sementara radikalisasi perilaku adalah proses individu mengadopsi pandangan hidup yang radikal kemudian transformasi perilaku yang mengarah ke suatu kondisi untuk bersedia melakukan tindakan kekerasan. Radikalisasi menyiratkan adanya transformasi intelektual dan ideologi ekstremis yang mendasari sebuah tindakan kekerasan (Crone, 2016). Dari definisi tersebut, dapat diambil pengertian bahwa radikal berada dalam pikiran, namun juga bisa termanifestasi dalam tindakan kekerasan dan terorisme.

Isu-isu radikalisme tidak hanya selalu terkait dengan agama. Doosje et al. (2016) mencatat bahwa radikalisme bisa terjadi karena isu nasionalisme dan separatisme seperti gerakan perjuangan kemerdekaan sebuah daerah dari penguasa. Isu yang lain adalah isu yang diangkat dalam gerakan ekstrem sayap kanan, misalnya isu-isu rasisme. Sebaliknya, isu dari gerakan ekstrem sayap kiri seperti isu tentang ketidakadilan dalam kesejahteraan. Ada juga tentang isu-isu spesifik yang dianggap relevan untuk diangkat oleh kelompok tertentu, seperti yang terjadi dalam kasus-kasus aborsi dan penyelamatan satwa. Isu-isu ini akan muncul menjadi gerakan radikal tergantung dari penilaian kelompok pelaku pada pentingnya isu, baik secara individu, kelompok, maupun dalam masyarakat luas. Psikologi menjadi disiplin ilmu yang memiliki tanggung jawab penting untuk memerangi radikalisme dan terorisme karena: (1) Nilai dan keyakinan yang diinterpretasikan secara subjektif sering 
berfungsi sebagai dasar paling penting untuk aksi teroris (Moghaddam, 2005); (2) Tindakan teroris dilakukan berkaitan dengan pengalaman psikologis tertentu yaitu, teror dan rasa ketidakberdayaan (Moghaddam \& Marsella, 2004); dan (3) terorisme sering kali memiliki konsekuensi psikologis yang sangat berbahaya (Moghaddam, 2005; Schlenger et al, 2002).

Radikalisasi menuju aksi terorisme adalah sebuah proses kompleks yang ditunjukkan secara bervariasi, seperti ideologi ekstrem, kelompok atau gerakan tempat anggota bergabung, dan karakteristik serta pengalaman masing-masing individu (Smith, 2018). Risiko keterlibatan individu dalam aksi ekstrem ditentukan oleh rangkaian sikap umum yang dibentuk atas dasar kebutuhan dan situasi sosial. Sikap umum ini adalah cara untuk mengimplementasikan kebutuhan, menentukan pendapat dan kegiatan spesifik, serta mendefinisikan pencarian ideologi yang cocok (Davydov, 2017a). Davydov (2017a) menyebutkan beberapa aspek dalam pengukuran radikalisme, yaitu: tunduk pada kuasa (cult of power), persetujuan terhadap agresivitas (admissibility of agression), intoleransi (intolerance), sifat tradisional (conventionalism), pesimisme sosial (social pessimism), kebatinan (mysticism), merusak dan sinis (destructiveness and cynicism), minat terhadap perubahan (passion for movement), nihilisme normatif (normative nihilsm), anti introspeksi (anti-introspection), dan konformitas (conformity).
Proses individu atau kelompok yang mulai mengadopsi ideologi ekstrem, baik dalam hal politik, sosial, dan agama, disebut dengan radikalisasi (Borum, 2011). Radikalisasi adalah masalah yang sangat kompleks, di dalamnya ada berbagai elemen datang bersama-sama, di mana tidak ada satu ukuran cocok untuk berbagai tindakan ekstrem yang terjadi. Radikalisasi dan ekstremisme merupakan beragam fenomena yang beroperasi secara berbeda untuk orang yang berbeda (Crone, 2016). Penelitian yang dilakukan oleh Smith (2018) mengenai asesmen potensi radikalisme terdiri dari beberapa faktor, yakni: (a) pernah melakukan tindakan kriminal, (b) perilaku anti-sosial, (c) memiliki masalah dengan kesehatan mental, (d) memiliki masalah dengan keluarga atau orang terdekat lainnya, (e) bergabung dengan kelompok ekstrem, (f) kekecewaan politik, dan (g) permasalahan pada bidang ekonomi.

Menurut penelitian yang dilakukan oleh Kurniawan et al. (2018), salah satu ciri berpikir seseorang yang terpapar terorisme merupakan konsep berpikir yang cenderung tertutup (need for closure). Hal ini dikarenakan konsep berpikir yang cenderung tertutup menyebabkan cara pikir yang kaku dan merasa tidak membutuhkan informasi yang lebih luas dalam pengambilan keputusan dan pemerolehan informasi. Kecenderungan berpikir tertutup didefinisikan sebagai keinginan individu untuk memperoleh ketegasan jawaban atau suatu kesimpulan 
secara cepat sebagai lawan dari kebingungan dan ketidakpastian (Kruglanski et al., 2006).

Menentukan pilihan, penilaian, dan keputusan merupakan bagian dari kehidupan sehari-hari manusia. Pilihan seorang individu antara satu dan yang lain cenderung sangat beragam. Meskipun demikian, individu dapat menunjukkan stabilitas yang cukup besar pada cara mereka mengambil keputusan dalam suatu situasi tertentu (Roats, 2007). Pada aksi terorisme dan radikalisme, proses perubahan untuk memutuskan dan melakukan teror dari seorang yang bukan pelaku teror menjadi seorang radikal diawali dengan proses radikalisasi pemikiran. Sikap dan pemikiran radikal seseorang juga dipengaruhi dengan berbagai faktor lainnya, seperti solidaritas dan persepsi ketidakadilan (Chusniyah, 2012; Kruglanski et al., 2014; Kurniawan et al., 2018; Milla et al., 2012; Moghadam, 2006; Talbot, 2008). Salah satu aspek psikologi yang berperan dalam pengambilan keputusan untuk melakukan tindakan radikal adalah kecenderungan berpikir tertutup atau biasa dikenal dengan istilah need for closure (Kruglanski et al., 2015; Kurniawan et al., 2018). Kecenderungan berpikir tertutup merupakan kebutuhan dalam mendapatkan suatu keputusan dan jawaban dengan cepat karena sulit untuk menerima ketidakpastian (Kurniawan et al, 2018).

Penelitian yang dilakukan oleh Milla (2008) menunjukkan bahwa pengambilan keputusan seorang anggota atau pengikut yang direkrut untuk melakukan aksi radikal ataupun teror cenderung memiliki keterbatasan dalam informasi yang mereka miliki. Selain itu, mereka mudah percaya pada pemimpin jemaah organisasi yang menyebabkan informasi mengenai hal-hal seperti mengapa dan bagaimana, menjadi tidak penting. Menurut teori keterbatasan rasionalitas yang diungkapkan oleh Kahneman (Milla, 2008), seseorang dalam mengambil keputusan dapat dibatasi oleh informasi yang kurang memadai dan pencarian solusi mengenai permasalahan yang terjadi. Hal tersebut sesuai dengan konsep kecenderungan berpikir tertutup, yaitu tidak menghendaki pemerolehan informasi yang utuh dalam pengambilan keputusan.

Aspek psikologis yang berkaitan dengan faktor risiko dan potensi yang dapat meradikalkan, perlu penyelidikan lebih lanjut untuk berkontribusi sebagai satu perspektif yang terintegrasi dalam teori yang lebih komprehensif (Mandel, 2009; David Webber \& Kruglanski, 2018). Penyelidikan aspek psikologis seperti itu dihubungkan dengan dinamika motivasi pada radikalisasi, termasuk penelitian yang dilakukan secara personal (Kruglanski et al., 2014) seperti perasaan ketidakpastian diri (Hogg, 2007), berjuang untuk kepastian, dan mengurangi ambiguitas melalui penutupan kognitif (Webber et al., 2018). Seperti penelitian yang dilakukan oleh Webber dan Kruglanski (2018) yang menunjukkan bahwa perasaan ketidakberdayaan akan meningkatkan 
ketertarikan terhadap ideologi ekstrem melalui kecenderungan berpikir tertutup.

Radikalisme tidak timbul begitu saja, terdapat proses panjang karena melibatkan aktor dan waktu di dalamnya. Titik awal dari proses radikalisme bersinggungan dengan realitas dari aksi perang dan teror. Proses radikalisme kini berkonsentrasi pada kehidupan setelah kematian sebagai imbalan atas pertempuran yang dilakukan (Nilsson, 2018). Penerimaan kematian atau bahkan kehilangan keinginan untuk hidup di dunia menjadikan sebagian orang menganggap aksi teror menjadi suatu hal yang dianggap wajar, sehingga pada akhirnya menyebabkan hilangnya empati terhadap korban teror atau kekerasan. Sebelum terpapar ideologi radikal, orang-orang yang melakukan aksi teror sebelumnya menganggap bahwa teror merupakan suatu tindakan yang salah. Orangorang yang melakukan aksi teror dan radikal memiliki kecenderungan untuk melakukan pembelaan dan pembenaran diri setelah mereka melakukan sesuatu yang salah. Suatu keadaan saat mereka membenarkan tindakan dan keputusan yang salah, terutama orang-orang yang tidak konsisten dengan keyakinan dan norma sebelumnya, berasal dari perasaan yang disebut disonansi kognitif, yaitu suatu bentuk ketidaknyamanan psikologis (Nilsson, 2018).

Inkonsistensi yang terjadi berkaitan dengan nilai salah dan benar suatu tindakan yang dilakukan oleh seseorang. Selanjutnya, hal ini dapat menjadi salah satu potensi pembenaran terhadap perilaku kekerasan di kemudian hari. Meski demikian, tentu hal ini berlawanan dengan pemaparan sebelumnya mengenai kebutuhan akan kepastian yang diindikasikan memiliki preferensi untuk keteraturan dan prediktabilitas, yakni memiliki kebutuhan untuk aman, konstan, dan pengetahuan yang stabil (Brizi, 2016).

Selanjutnya, Slootman dan Tillie (2006) berpendapat bahwa radikalisasi melibatkan kontak dengan pemimpin karismatik dalam kelompok kecil yang terisolasi dari masyarakat. Pada beberapa kasus yang terjadi, orang-orang yang bersedia menjadi bagian dari sekte atau aliran radikal memiliki rasa kepatuhan yang tinggi. Salah satu faktor kepribadian seseorang yang erat kaitannya dengan kepatuhan adalah kecenderungan kebersetujuan (agreeableness). Seseorang dengan kecenderungan kebersetujuan yang tinggi cenderung mudah percaya, mudah mengalah, mudah menerima, menghargai orang lain, dan berperilaku baik (Feist \& Feist, 2008). Sedangkan orang dengan skor kecenderungan kebersetujuan yang rendah cenderung tidak mudah patuh, mudah protes, dan antagonis. Kecenderungan kebersetujuan merupakan bagian dari Big Five Personality yang mengacu pada kecenderungan untuk tunduk pada orang lain (Pratama, 2012). Big Five Personality merupakan faktor kerangka kepribadian yang bersifat universal yang digunakan untuk mengukur kepribadian secara komprehensif (Lounsbury \& Gibson, 1998). 
Penelitian yang dilakukan oleh Piedmont et al. (2002) menunjukkan bahwa terdapat hubungan antara sikap agresi dan kepribadian dengan kecenderungan kebersetujuan. Kemudian, penelitian yang dilakukan oleh Brandstatter dan Opp (2014) menghasilkan kesimpulan bahwa seseorang dengan tingkat kecenderungan kebersetujuan yang tinggi cenderung akan protes pada sistem atau hasil politikyang ada. Kecenderungan kebersetujuan adalah faktor Big Five Personality yang menilai orientasi perasaan kepercayaan dan kesetujuan seseorang kepada orang lain dalam perasaan, pemikiran, maupun tindakan (Pervin et al., 2012). Rasa kepercayaan dan kepatuhan yang tinggi memungkinkan seseorang untuk mudah menerima dan mematuhi informasi-informasi baru yang diterima, dalam hal ini adalah informasi mengenai ideologi radikal. Adapun penelitian Alizadeh et al. (2017) menunjukkan bahwa orang-orang yang mengikuti akun ekstremis di sosial media memiliki tingkat kecenderungan kebersetujuan yang rendah.

Penelitian ini bertujuan untuk mendapatkan gambaran tingkat kecenderungan berpikir tertutup, kecenderungan kebersetujuan, dan potensi perilaku radikal pada mahasiswa, serta menguji pengaruh kecenderungan kebersetujuan dan kecenderungan kebersetujuan terhadap perilaku radikal pada mahasiswa. Penelitian yang mengaitkan aspek kognitif dan kepribadian dengan perilaku radikal belum banyak dilakukan di Indonesia.
Oleh karena itu, penelitian ini diharapkan mampu memberikan pemahaman yang lebih mendalam mengenai prediktor bagi potensi perilaku radikal pada subjek di Indonesia.

\section{Metode}

\section{Subjek penelitian}

Penelitian ini melibatkan sebanyak 314 orang mahasiswa sebagai subjek penelitian dengan rentang usia antara 17 - 24 tahun. Dari sisi jenis kelamin, 198 subjek berjenis kelamin perempuan dan 116 subjek berjenis kelamin laki-laki. Berdasarkan asal fakultas, penelitian ini melibatkan 107 mahasiswa dari Fakultas Sains dan Teknologi, 40 mahasiswa dari Fakultas Tarbiyah, 70 mahasiswa dari Fakultas Humaniora dan Budaya, 72 mahasiswa dari Fakultas Psikologi, 10 mahasiswa dari Fakultas Syariah, dan 13 mahasiswa dari Fakultas Ekonomi.

\section{Metode pengumpulan data}

Penelitian ini menggunakan tiga skala sebagai berikut:

\section{Need for Closure Scale}

Need for Closure Scale versi singkat(Roats \& Van Heil, 2011; Webster \& Kruglanski, 1994) digunakan untuk mengukur need for closure pada mahasiswa. Skala ini diadaptasi dengan menggunakan metode forward translation yang dimulai dengan menerjemahkan secara konseptual sehingga dapat dipahami oleh subjek penelitian. Skala ini terdiri dari 12 butir pernyataan. Salah satu contoh butir pernyataannya 
adalah "Saya tidak suka berada pada situasi yang tidakjelas". Penelitian ini menunjukkan reliabilitas Alpha Cronbach sebesar .642. Nilai reliabilitas ini masih cukup relevan untuk digunakan dalam sebuah riset Hal ini berdasarkan pendapat Weiner dan Stewart (1984) yang menyatakan bahwa, nilai reliabilitas .6 - .7 masih relevan untuk sebuah instrumen pengukuran untuk dapat digunakan dalam sebuah penelitian.

\section{Big Five Inventory Scale}

Big Five Inventory Scale (John \& Srivastava, 1999) khusus pada dimensi kecenderungan kebersetujuan untuk mengukur kecenderungan kebersetujuan pada mahasiswa. Skala ini diadaptasi dengan menggunakan metode forward translation. Skala ini terdiri dari sembilan butir pernyataan. Salah satu contoh butir pernyataannya adalah "Saya memiliki kecenderungan mencari-cari kesalahan orang lain". Penelitian ini menunjukkan reliabilitas Alpha Cronbach sebesar.639. Mengacu pada pendapat Weiner dan Stewart (1984), nilai Alpha Cronbach tersebut menunjukkan bahwa skala ini masih relevan digunakan untuk penelitian.

\section{Disposition Violent Extremism Scale}

Skala Disposition Violent Extremism Scale (Davydov, 2017b) digunakan untuk mengukur potensi radikalisme mahasiswa. Pemilihan skala ini dilakukan dengan mempertimbangkan kesesuaian budaya subjek penelitian. Skala ini diadaptasi dengan menggunakan metode forward translation. Skala ini terdiri dari 66 butir pernyataan. Salah satu contoh butir pernyataannya adalah "Sangat memungkinkan jika seseorang dari suku atau ras lain menjadi teman saya". Penelitian ini menunjukkan reliabilitas Alpha Cronbach sebesar .819.

\section{Metode analisis data}

Data yang diperoleh dalam penelitian ini dianalisis menggunakan metode analisis deskriptif untuk mengetahui tingkat kecenderungan berpikir tertutup, kepribadian kebersetujuan dan perilaku radikal. Setelah itu, peneliti melakukan uji hipotesis dengan menggunakan metode uji regresi untuk mengetahui apakah variabel kecenderungan berpikir tertutup dan kepribadian kebersetujuan dapat menjadi prediktor bagi potensi perilaku radikal.

\section{Hasil}

Hasil yang didapatkan dalam Tabel 1 menunjukkan bahwa tingkat kecenderungan berpikir tertutup mahasiswa cenderung tinggi. Hal ini terlihat dari adanya 157 subjek (50\%) yang memiliki kecenderungan berpikir tertutup dalam kategori sedang, kemudian diikuti oleh adanya 156 subjek (49.7 \%) yang memiliki kecenderungan berpikir tertutup dalam kategori tinggi. Sementara itu, hanya terdapat satu subjek $(0.3 \%)$ yang memiliki kecenderungan berpikir tertutup dalam kategori rendah.

Hasil yang hampir sama juga ditemukan pada kecenderungan kebersetujuan. Hasil pengumpulan data 
menunjukkan bahwa mahasiswa memiliki tingkat kecenderungan kebersetujuan pada rentang sedang hingga tinggi. Terdapat 135 subjek (43\%) yang memiliki kecenderungan kebersetujuan dalam kategori tinggi, dan 176 subjek (56.1\%) yang memiliki kecenderungan kebersetujuan dalam kategori sedang. Di sisi lain, terdapat tiga subjek (1\%) yang memiliki kecenderungan kebersetujuan dalam kategori rendah.
Dalam kategori potensi perilaku radikal, sebagian besar subjek berada dalam kategori sedang, ditunjukkan dengan adanya 301 subjek (97.8\%) yang memiliki potensi perilaku radikal pada kategori sedang. Sementara itu, terdapat satu subjek $(0.3 \%)$ yang memiliki potensi perilaku radikal pada kategori tinggi, dan enam subjek (1.9\%) yang memiliki potensi perilaku radikal pada kategori rendah. Hasil penelitian ini akan dijelaskan lebih lanjut.

Tabel 1

Kategorisasi Variabel Penelitian

\begin{tabular}{lcccccc}
\hline \multirow{2}{*}{ Kategori } & \multicolumn{2}{c}{$\begin{array}{c}\text { Kecenderungan } \\
\text { berpikir tertutup }\end{array}$} & \multicolumn{2}{c}{$\begin{array}{c}\text { Kecenderungan } \\
\text { kebersetujuan }\end{array}$} & \multicolumn{2}{c}{ Perilaku Radikal } \\
\cline { 2 - 7 } & $n$ & $\%$ & $n$ & $\%$ & $n$ & $\%$ \\
\hline Tinggi & 156 & 49.7 & 135 & 43 & 1 & 0.3 \\
Sedang & 157 & 50 & 176 & 56.1 & 301 & 97.8 \\
Rendah & 1 & 0.3 & 3 & 1 & 6 & 1.9 \\
$N$ & 314 & 100 & 314 & 100 & 314 & 100 \\
\hline
\end{tabular}

Lebih lanjut dalam penelitian ini juga dilakukan analisis untuk menunjukkan aspek dari potensi perilaku radikal mahasiswa melalui penghitungan skor tiap aspek. Sebagaimana terlihat pada Gambar 1, hasil pengumpulan data menunjukkan bahwa subjek cenderung memiliki nilai yang tinggi pada aspek kebatinan dan aspek merusak dan sinis. Aspek kebatinan merujuk pada pembenaran yang dilakukan seseorang terhadap kekerasan dan korban atas dasar kepercayaan mistis tertentu (Davydov, 2017a). Selain itu, ia cenderung memiliki kepercayaan mistis yang sering dihubungkan dengan permasalahan negara. Adapun aspek merusak dan sinis merujuk pada kecurigaan terhadap niat seseorang dalam berperilaku dan ketidakmampuan memiliki rasa belas kasih pada seseorang yang telah dianggap sebagai musuh (Daydove, 2017). 


\section{Gambar 1}

Proporsi Aspek Potensi Perilaku Radikal

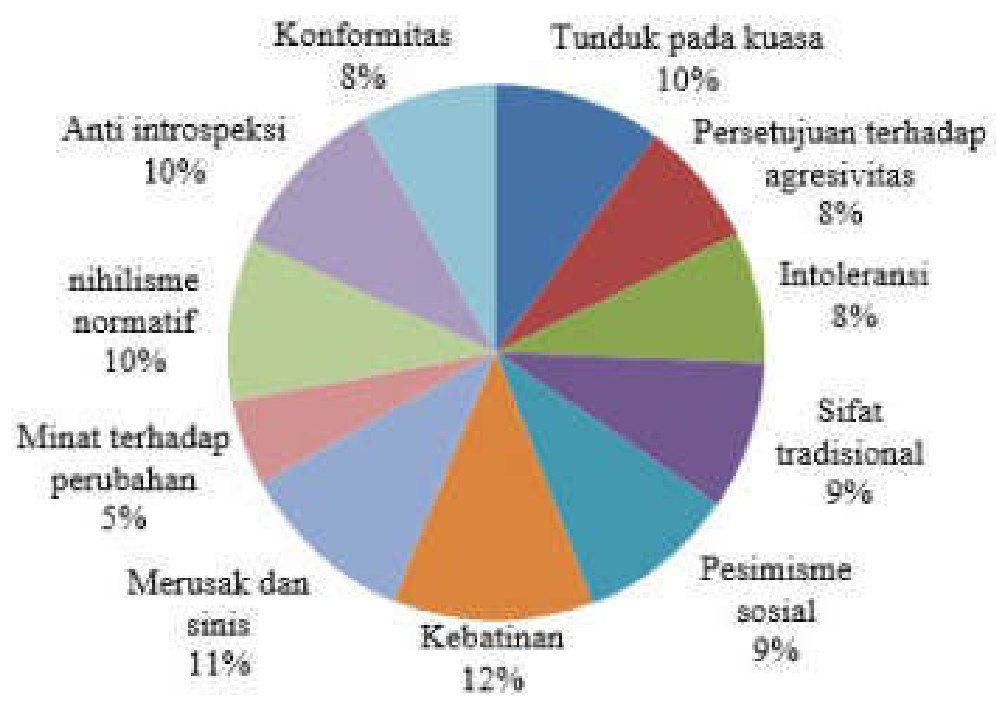

Data yang diperoleh kemudian dianalisis menggunakan analisis regresi. Hasil uji hipotesis data menunjukkan koefisien korelasi sebesar $.326(p=.000, p<.01)$. Hal ini menunjukkan bahwa hipotesis penelitian diterima, artinya terdapat pengaruh secara simultan antara kecenderungan berpikir tertutup dan kecenderungan kebersetujuan terhadap potensi radikal. Diketahui pula nilai koefisien determinasi sebesar .106 yang menunjukkan bahwa kecenderungan berpikir tertutup dan kecenderungan kebersetujuan berpengaruh $10.6 \%$ terhadap kecenderungan radikalisme mahasiswa.

Adapun secara parsial, pada variabel kecenderungan berpikir tertutup diperoleh nilai koefisien korelasi sebesar .254 ( $p=000, p$
$<.01$. Artinya, penelitian ini menunjukkan adanya pengaruh positif kecenderungan berpikir tertutup terhadap kecenderungan radikal pada mahasiswa. Selanjutnya, pada variabel kecenderungan kebersetujuan diperoleh nilai koefisien korelasi sebesar -.241 $(p=.00, p<.01)$. Artinya, kecenderungan kebersetujuan berpengaruh negatif terhadap kecenderungan radikal pada mahasiswa. Berdasarkan hasil temuan tersebut dapat disimpulkan bahwa, semakin tinggi tingkat kecenderungan berpikir tertutup pada mahasiswa, semakin tinggi pula potensi radikalisme yang akan muncul, dan semakin tinggi tingkat kecenderungan kebersetujuan pada mahasiswa, semakin rendah potensi radikalisme yang akan muncul. 


\section{Tabel 2}

Hasil Analisis Regresi

\begin{tabular}{lccc}
\hline \multicolumn{1}{c}{ Variabel } & $R$ & $R^{2}$ & $p$ \\
\hline $\begin{array}{l}\text { Kecenderungan berpikir tertutup * Perilaku } \\
\text { radikal }\end{array}$ & $.254^{* *}$ & - & .000 \\
$\begin{array}{l}\text { Kecenderungan kebersetujuan * Perilaku radikal } \\
\text { Kecenderungan berpikir tertutup * }\end{array}$ & $-.241^{* *}$ & - & .000 \\
Kecenderungan kebersetujuan* Perilaku radikal & $.326^{* *}$ & .106 & .000 \\
\hline $\begin{array}{l}\text { Catatan. Variabel terikat = potensi perilaku radikal; variabel bebas = kecenderungan } \\
\text { berpikir tertutup, kecenderungan kebersetujuan; }{ }^{* *} p<.01 .\end{array}$
\end{tabular}

\section{Pembahasan}

Penelitian ini bertujuan untuk mendapatkan gambaran tingkat kecenderungan berpikir tertutup, kecenderungan kebersetujuan dan potensi perilaku radikal pada mahasiswa, serta menguji pengaruh kecenderungan berpikir tertutup dan kecenderungan kebersetujuan terhadap perilaku radikal pada mahasiswa. Hasil analisis data menunjukkan subjek dalam penelitian ini memiliki tingkat kecenderungan berpikir tertutup dan kecenderungan kebersetujuan yang tinggi. Meski demikian, tingkat perilaku radikal subjek berada pada kategori sedang.

Mahasiswa dengan rentang usia $17-24$ tahun menjadi kelompok yang rentan untuk menjadi sasaran ideologi radikal. Mereka memiliki tingkat minat terhadap perubahan yang tinggi (Davydov, 2017). Artinya, mereka cenderung menyukai petualangan, perubahan, dan transformasi. Di samping itu, mahasiswa juga sedang berada pada masa pencarian ideologi yang cocok dengan dirinya. Mereka akan cenderung mengidentifikasi kelompok yang menarik baginya. Hal tersebut menjadikan mahasiswa dapat terpapar ideologi radikal.
Nilai skor agresi yang rendah dapat disebabkan oleh tingkat kecenderungan kebersetujuan yang tinggi pada mahasiswa. Individu dengan tingkat kecenderungan kebersetujuan yang tinggi cenderung merasa simpatik, lemah lembut, dan bersikap kooperatif, sehingga sulit untuk menerima atau menampilkan sikap agresif. Selain itu, nilai yang rendah dalam minat terhadap perubahan dapat disebabkan oleh kekhawatiran pada hasil dari transformasi tersebut. Beberapa pemuda yang memiliki minat rendah pada perubahan dan transformasi dapat disebabkan karena kecemasan mengenai hasil setelah dilakukan perubahan. Hasil penelitian yang dilakukan oleh Chernikova et al. (2017) mengenai kecenderungan berpikir tertutup terhadap inovasi yang dimediasi oleh kecemasan menunjukkan bahwa seseorang dengan kecenderungan berpikir tertutup tinggi menunjukkan minat yang rendah untuk melakukan suatu inovasi. Minat yang rendah dalam perubahan dapat membuat individu cenderung kaku dalam berpikir dan berperilaku.

Secara umum, sebagai komunitas calon ilmuwan dan agen perubahan serta pemimpin 
masa depan, seharusnya mahasiswa memiliki potensi radikal yang rendah dan daya kritis yang baik atau kecenderungan berpikir tertutup yang rendah pula. Keberadaan hasil uji deskripsi dan korelasi dalam penelitian ini meniscayakan perhatian yang besar pada manajemen kampus untuk benar-benar memperhatikan pembinaan mahasiswa serta memperhatikan sumber belajar, dalam hal ini referensi dan dosen, agar benar-benar aman dari pemikiran radikal. Kehati-hatian ini tidak harus sampai memberikan tindakan represif yang kemudian akan menciptakan reaktansi sikap radikal. Data potensi radikal pada kategori sedang, dapat mencuat menjadi manifes jika tidak dilakukan tindakan yang baik dan terarah.

Hasil uji regresi menunjukkan bahwa kecenderungan berpikir tertutup dan kecenderungan kebersetujuan berpengaruh pada kecenderungan perilaku radikal pada mahasiswa. Hasil ini menunjukkan jika semakin tinggi tingkat kecenderungan berpikir tertutup individu, maka semakin tinggi pula kecenderungan untuk berperilaku radikal. Mereka akan cenderung memutuskan untuk keluar dari suatu keadaan ketidakpastian diri dan berjuang untuk kepastian dengan mengurangi ambiguitas yang dirasakan (Kruglanski et al., 2006). Oleh sebab itu, ketika dihadapkan pada suatu tawaran yang bersifat memberikan kepastian dengan mengadopsi cita-cita, ide, dan aspirasi yang lain berkaitan dengan politik, sosial, atau agama, mereka akan dengan cepat menerimanya. Apabila tidak dihadapkan pada suatu penawaran dengan berbagai alternatif tertentu, kecenderungan berpikir tertutup akan mendorong seseorang untuk meningkatkan keinginan mengidentifikasi suatu kelompok yang menyediakan pilihan yang bersifat lebih realistis (Hardin \& Higgins, 1996).

Penelitian ini sejalan dengan penelitian yang dilakukan oleh Gambetta dan Hertogg (2009) yang menemukan bahwa terdapat tingkat kecenderungan berpikir tertutup yang tinggi pada sebagian besar pelaku teror. Artinya, jika kecenderungan berpikir tertutup tinggi, maka kecenderungan untuk melakukan aksi radikal tinggi, begitu pula sebaliknya. Individu dengan kecenderungan berpikir tertutup yang rendah cenderung akan mempertimbangkan banyak hal dan membutuhkan informasi yang lebih banyak untuk pengambilan suatu kesimpulan. Oleh sebab itu, mereka cenderung membutuhkan pertimbangan yang banyak apabila ditawarkan untuk mengadopsi ide dan cita-cita yang baru.

Penelitian lain yang dilakukan oleh Kurniawan et al. (2018) menunjukkan bahwa salah satu tujuan dari proses deradikalisasi yang dilakukan pada pelaku teror bertujuan untuk menurunkan kecenderungan berpikir tertutup para narapidana. Hal ini disebabkan karena ditemukannya kecenderungan berpikir tertutup yang tinggi pada narapidana pelaku teror. Kecenderungan berpikir tertutup yang 
tinggi akan membuat individu menolak berbagai macam alternatif pilihan saat mempertimbangkan suatu keputusan akhir (Choi et al, 2008; Houghton \& Grewal, 2000; Kurniawan et al., 2018).

Kecenderungan yang tinggi untuk mengadopsi cita-cita atau ideologi dengan ekstrem atau radikal akan memunculkan berbagai macam perilaku pada individu. BNPT (2012) menyatakan bahwa terorisme di Indonesia akan terus berkembang jika terus dipupuk. Sedangkan radikalisme adalah pupuk dari aksi terorisme. Kecenderungan berpikir tertutup yang tinggi memberikan sumbangsih dalam ketertarikan individu pada ideologi radikal dan pengambilan keputusan untuk melakukan aksi teror.

Seseorang yang telah terpapar ideologi radikal biasanya akan menyuarakan pemahaman mereka. Ketika hal tersebut dianggap tidak cukup, ia akan melakukan kekerasan atau tindakan ekstrem meski harus mengorbankan diri untuk mencapai tujuan atau merusak status quo yang ada. Individu ini memiliki toleransi yang rendah dan menutup diri dari lingkungan. Ia akan mengategorikan lingkungannya menjadi dua bagian, yaitu kawan dan lawan. Mahasiswa yang terpapar akan cenderung membatasi diri dengan lingkungan sosialnya, berpikiran tertutup, mudah menyalahkan orang lain, menganggap bahwa terdapat banyak kecurangan dalam demokrasi, hingga keyakinan kuat untuk mengorbankan diri sendiri.
Kruglanski et al. (2014) menyebutkan bahwa radikalisasi dimulai dengan membangkitkan semangat untuk pencapaian tujuan penting yang aktual secara signifikan melalui kekerasan, stigma, penghinaan, dan pengambilan hak, sehingga perlu adanya upaya untuk mendapatkan tujuan tersebut di dunia sosial. Posisi ideologi adalah memfasilitasi dalam pencapaian tujuan penting tersebut. Hasil penelitian yang dilakukan oleh Lakey et al (2010) menunjukkan bahwa kecenderungan berpikir tertutup dapat memainkan peran penting dalam diri individu sebagai respon sosial yang muncul akibat fenomena sosial tertentu. Sedangkan hasil penelitian yang dilakukan oleh Chernikova et al. (2017) mengenai kecenderungan berpikir tertutup terhadap inovasi yang dimediasi oleh kecemasan menunjukkan bahwa seseorang dengan kecenderungan berpikir tertutup tinggi menunjukkan minat yang rendah untuk melakukan suatu inovasi. Hal ini dikarenakan kecemasan mereka mengenai hasil dari inovasi teknologi tersebut.

Upaya menurunkan potensi radikalisme di kalangan mahasiswa adalah dengan adanya suatu perlakuan untuk menurunkan tingkat kecenderungan berpikir tertutup yang tinggi. Menurut Kruglanski dan Webster (1994), individu dengan kecenderungan berpikir tertutup yang rendah akan memiliki pemikiran yang lebih terbuka, membutuhkan banyak informasi terlebih dahulu sebelum menentukan suatu kesimpulan, serta tidak tergesa-gesa 
dalam menentukan keputusan. Sebaliknya, individu dengan kecenderungan berpikir tertutup yang tinggi cenderung kaku, berpikiran baku dan tertutup, menyukai keteraturan, ketidakmampuan untuk bertahan pada situasi yang ambigu, dan keinginan yang tinggi untuk mendapatkan solusi dengan cepat.

Menurut Costa dan McCrae (Brandstätter \& Opp, 2014) kecenderungan kebersetujuan adalah salah satu sifat dalam kepribadian individu yang mengukur kualitas dari tindakan yang dilakukan seseorang terhadap orang lain. Kecenderungan kebersetujuan dicirikan dari sikap kooperatif, senang membantu sesama, toleran, dan simpati. Selain itu, kecenderungan kebersetujuan yang tinggi diartikan dengan lemah lembut, terus terang, dan mudah percaya. Berdasarkan hasil uji hipotesis penelitian ini, ditemukan bahwa kecenderungan kebersetujuan memiliki pengaruh yang signifikan terhadap kecenderungan radikalisme mahasiswa. Seseorang dengan kecenderungan kebersetujuan yang tinggi ditandai dengan karakteristik sulit untuk mengklaim dirinya lebih baik dari orang lain. Artinya, ia cenderung menempatkan dirinya pada posisi berbenah diri (internal) dibanding menyalahkan orang lain atau keadaan lingkungannya (eksternal). Oleh sebab itu, jika dihadapkan pada permasalahan sosial, politik, dan agama, individu dengan tingkat kecenderungan kebersetujuan yang tinggi akan cenderung mengevaluasi diri dan mengatasinya dengan memberikan performa yang baik dalam upaya mencapai tujuan.

Individu dengan kecenderungan kebersetujuan yang rendah cenderung tidak bersahabat, etnosentris, pendiam, kurang kooperatif, memiliki kecurigaan yang tinggi, senang mengkritik, dan manipulatif (Brandsatter \& Opp, 2014). Adapun mahasiswa yang memiliki skor kecenderungan kebersetujuan yang rendah akan cenderung melakukan kemalasan sosial (social loafing) dalam melakukan tugas kelompok (Schippers, 2014). Artinya, mahasiswa ini kurang menunjukkan performa yang baik dalam penyelesaian tugas kelompok karena keinginan untuk terlibat dalam mencapai tujuan kelompok tergolong rendah serta kurangnya kemampuan bekerja secara kooperatif.

Penelitian yang dilakukan oleh Chirumbolo dan Leeone (2010) menunjukkan bahwa individu dengan tingkat kecenderungan kebersetujuan yang tinggi memperhatikan kesejahteraan dan solidaritas dan cenderung lebih mendukung partai sayap kiri (liberalisme). Di sisi lain, individu yang memiliki skor kecenderungan kebersetujuan rendah dalam sifat ini cenderung memberikan pilihan pada partai sayap kanan (konservatisme). Hal ini dikarenakan sikap altruisme yang tinggi pada individu dengan kecenderungan kebersetujuan yang tinggi memunculkan kecenderungan untuk memperhatikan kesejahteraan orang lain di sekitarnya. Adapun pada penelitian mengenai 
kecenderungan berpikir tertutup yang dilakukan Chirumbolo et al. (2004) menunjukkan bahwa, individu yang memiliki kecenderungan berpikir tertutup tinggi akan cenderung mendukung partai sayap kanan, sedangkan individu yang memiliki kecenderungan berpikir tertutup rendah akan cenderung memberikan dukungan pada partai sayap kiri.

Hasil penelitian lain yang sejalan dengan penelitian ini adalah penelitian yang dilakukan oleh Anderson dan Bushman (2002). Penelitian tersebut menunjukkan bahwa kecenderungan kebersetujuan memiliki hubungan negatif dengan perilaku kekerasan dan tindakan agresif. Artinya, semakin tinggi tingkat kecenderungan kebersetujuan seseorang, maka semakin rendah tingkat agresivitasnya. Dengan kata lain, individu yang memiliki kecenderungan kebersetujuan rendah cenderung lebih agresif dan kurang kooperatif. Hasil disposisi kecenderungan radikalisme pada penelitian ini menunjukkan bahwa responden memiliki tingkat agresivitas yang cenderung rendah dengan tingkat kecenderungan kebersetujuan yang cenderung tinggi.

Penelitian lain yang tidak sejalan dengan penelitian ini adalah penelitian yang dilakukan oleh Denson et al. (2006). Penelitian tersebut menunjukkan bahwa terdapat hubungan yang positif antara kecenderungan kebersetujuan dan agresivitas. Artinya, semakin tinggi tingkat kecenderungan kebersetujuan seseorang, semakin tinggi pula tingkat agresivitasnya.
Dalam menjelaskan hal ini, perlu untuk mengidentifikasi jenis agresivitas yang mungkin dimunculkan oleh individu dengan skor kecenderungan kebersetujuan yang tinggi. Menurut Taylor (2012), tipe agresi yang dapat dimunculkan adalah agresi sosial, di mana perilaku agresi ini disetujui oleh norma sosial. Misalnya, agresivitas yang dilakukan oleh penegak hukum dalam melaksanakan tugasnya.

Kecenderungan kebersetujuan yang tinggi pada mahasiswa dapat menjadi faktor pencegah terjadinya radikalisme meskipun tingkat kecenderungan berpikir tertutup mahasiswa berada pada kategori tinggi. Karakteristik individu dengan kecenderungan kebersetujuan yang tinggi ketika berhadapan dengan permasalahan akan cenderung menghindari konflik. Meski memiliki keinginan untuk keluar dari ambiguitas dan ketidakpastian diri yang cukup tinggi, individu ini akan cenderung menyelesaikan masalah dengan cara lemah lembut.

Potensi radikal pada penelitian ini menunjukkan bahwa subjek lebih mengarah pada aspek kebatinan, yakni merusak dan sinis. Crone (2016) menyebutkan bahwa sekelompok pemuda yang baru-baru ini terlibat dalam aksi terorisme di Eropa memiliki motif yang berbeda-beda. Beberapa dari mereka melakukan aksi didasarkan karena ketertarikan pada ideologi yang menjadi oposisi pemerintah, sedangkan sisanya melakukan aksi karena ketertarikan pada aksiaksi kekerasan semata. 
Kelompok yang melakukan aksi karena ketertarikan pada kekerasan biasanya memiliki latar belakang sosial yang bermasalah dan sebelumnya pernah melakukan tindakan kekerasan. Melalui aksinya, mereka mengharapkan suatu pengakuan, prestise, dan keberhasilan. Sedangkan yang melakukan aksi karena ketertarikan pada ideologi oposisi biasanya melewati proses radikalisasi yang panjang.

Berdasarkan kedua kelompok tersebut, dapat disimpulkan bahwa terdapat pola yang berbeda antara radikalisme yang dilakukan atas ideologi agama dan radikalisme yang bukan didasarkan pada ideologi agama. Radikalisme yang dilakukan atas ideologi agama didasarkan pada adanya tafsiran atau dalil-dalil agama sebagai penguatan dalam melakukan aksi. Sedangkan radikalisme nonagama tidak didasarkan pada dalil agama, akan tetapi keinginan untuk melakukan kekerasan. Dalam kasus ini, agama dijadikan sebagai simbol radikalisme.

Meskipun demikian, beberapa aspek yang mendapat nilai cukup rendah adalah intoleransi, agresi dan minat terhadap perubahan. Hal ini mengindikasikan bahwa subjek memiliki tingkat toleransi yang cukup baik, agresi yang dapat dikendalikan, dan kerelaan mengorbankan diri pada suatu ide yang cukup rendah.

Penelitian yang dilakukan oleh Shah et al. (1998) menunjukkan bahwa seseorang dengan kecenderungan berpikir tertutup yang tinggi memiliki toleransi yang tinggi dalam hal keberagamaan. Adapun dalam penelitian ini ditemukan nilai intoleransi yang relatif rendah meskipun mahasiswa memiliki tingkat kecenderungan berpikir tertutup yang tinggi. Nilai intoleransi yang rendah menunjukkan bahwa mahasiswa dapat bertoleransi dan menghargai perbedaan yang ada dalam lingkungannya. Hal ini dapat menurunkan kemungkinan mahasiswa untuk melakukan perusakan atau perombakan status quo ketika terdapat perbedaan-perbedaan di dalamnya.

Penelitian ini masih dapat dikembangkan menjadi penelitian yang lebih lanjut. Beberapa hal yang bisa dikembangkan adalah pengembangan tentang terminologi radikalisme, yakni perbedaan definisi radikal yang berakar pada agama dan nonagama. Selain itu penelitian ini belum menjawab pertanyaan tentang apakah radikalisme akan muncul jika dipicu oleh sasaran atau hanya bersifat laten. Artinya apakah faktor objek sikap juga memengaruhi secara kuat perilaku radikal.

\section{Simpulan}

Penelitian ini menunjukkan bahwa kecenderungan kebersetujuan memiliki pengaruh yang negatif pada potensi radikal mahasiswa, adapun kecenderungan berpikir tertutup mempunyai pengaruh positif pada potensi radikal mahasiswa.

\section{Saran}

Dari data dan pembahasan penelitian ini, dapat ditarik simpulan bahwa individu yang 
cenderung berpikir tertutup dapat memengaruhi peningkatan potensi perilaku radikal. Namun demikian, potensi perilaku radikal bisa diturunkan dengan karakteristik yang lebih memihak pada orang lain, yaitu kecenderungan kebersetujuan. Meskipun secara statistik, potensi ini masih berada pada taraf sedang, tetapi perlu kewaspadaan pada manajemen kampus agar potensi ini tidak menjadi perilaku yang nyata. Penelitian ini menyarankan untuk memperhatikan sumbersumber belajar, baik dosen, maupun referensi yang diakses oleh mahasiswa agar memberikan penanaman deradikalisasi sejak awal mahasiswa menjalani perkuliahan.

\section{Referensi}

Alizadeh, M., Weber, I., Cioffi-Revilla, C., Fortunato, S., \& Macy, M. (2017). Psychological and personality profiles of political extremists. arXiv preprint. https://arxiv.org/ftp/arxiv/papers / 1704/1704.00119.pdf

Anderson, C. A., \& Bushman, B. J. (2002). Human aggression. Annual Review of Psychology, 53, 27-51. https://doi.org/10.1146/ annurev.psych.53.100901.135231

Badan Nasional Penanggulangan Terorisme. (2012). Strategi menghadapi paham radikalisme terorisme-ISIS. Badan Nasional Penanggulangan Terorisme

Borum, R. (2011). Radicalization into violent extremism I: A review of social science theories. Journal of Strategic Security, 4(4), 1-36. https://doi.org/10.5038/ 1944-0472.4.4.1

Brandstätter, H., \& Opp, K. D. (2014). Personality traits ("Big Five") and the propensity to political protest: Alternative models. Political Psychology,
35(4), 515-537. https://doi.org/ $10.1111 /$ pops. 12043

Brizi, A. (2016). Entry for Need for closure. Encyclopedia of Personality and Individual Differences, 1-4. https:// doi.org/10.1007/978-3-319-280998_1092-1

Chernikova, M., Kruglanski, A., Giovannini, D., Loris, V., \& Junjie, S. (2017). Need for closure and reactions to innovation. Journal of Applied Social Psychology, 97106. https://doi.org/10.1111/ jasp.12451

Chirumbolo, A., Areni, A., \& Sensales, G. (2004). Need for cognitive closure and politics: Voting, political attitudes and attributional style. International Journal of Psychology, 39(4), 245-253. https:// doi.org/10.1080/00207590444000005

Chirumbolo, A., \& Leone, L. (2010). Personality and politics: The role of the HEXACO model of personality in predicting ideology and voting. Personality and Individual Differences, 49(1), 43-48. h t tp s : / / doi.org/10.1016/ j.paid.2010.03.004

Choi, J. A., Koo, M., Choi, I., \& Auh, S. (2008). Need for cognitive closure and information search strategy. Psychology \& Marketing, 25(11), 1027-1042. https:/ /doi.org/10.1002/mar.20253

Chusniyah, T. (2012). Sikap terhadap penegakan khilafah-syariah: Model struktural dari kelompok HTI, JAT dan MMI. Jurnal Psikologi Tazkiya, 12(2), 601-614.

Crone, M. (2016). Radicalization revisited: violence, politics and the skills of the body. In The Royal Institute of International Affairs (pp. 587-596). John Wiley \& Sons.

Davydov, D. G. (2017a). The personal dispositions of violent extremism. Psikhologiia i Pravo [Psychology and Law], 7(1), 106-121. https://doi.org/ 10.17759/psylaw.2017070109 
Davydov, D. G. (2017b). Youth extremism scale. Modern University for the Humanities.

Denson, T. F., Pedersen, W. C., \& Miller, N. (2006). The displaced aggression questionnaire. Journal of Personality and Social Psychology, 90(6), 1032-1051. https:// doi.org/10.1037/0022-3514.90.6.1032

Doosje, B., Moghaddam, F. M., Kruglanski, A. W., de Wolf, A., Mann, L., \& Feddes, A. R. (2016). Terrorism, radicalization and deradicalization. Current Opinion in Psychology, 11, 79-84. https://doi.org/ 10.1016/j.copsyc.2016.06.008

Feist, J., \& Feist, G. J. (2008). Theories of personality (6th ed.). Pustaka Pelajar.

Gambetta, D., \& Hertog, S. (2009). Why are there so many Engineers among Islamic Radicals? European Journal of Sociology, 50(2), 201-230. https://doi.org/ $10.1017 /$ S0003975609990129

Hammad, A. M. (2018). Radikalisme di kalangan mahasiswa Surabaya. Universitas Islam Negeri Surabaya.

Hardin, C. D., \& Higgins, E. T. (1996). Shared reality: How social verification makes the subjective objective. In R. M. S. \& E. T. Higgins (Ed.), Handbook of motivation and cognition (pp. 28-84). The Guilford Press.

Hendropriyono, A. (2009). Terorisme/: Fundamentalis Kristen, Yahudi, Islam. Penerbit Buku Kompas.

Hogg, M. A. (2007). Uncertainty-identity theory. In M. P. Zanna (Ed.), Advances in experimental social psychology: Vol 39. Advances in experimental social psychology, Vol 39 (pp.69-126). Elsevier Academic Press.

Houghton, D. C., \& Grewal, R. (2000). Please, let's get an answer-any answer: Need for consumer cognitive closure. Psychology \& Marketing, 17(11), 911-934. https:// do i. or g/ $10.1002 / 1520$ $6793(200011) 17: 11<911:$ :AID MAR1>3.0.CO;2-4
Jamaluddin, M., Eliott, C., McLaughlin, \& Cullinane, S. (2018). Family of suicide bombers attacks 3 churches in Indonesia, killing 7 , police say. CNN. https:// edition.cnn.com/2018/05/13/asia/ indonesia-church-attacks-surabaya/ index.html

John, O. P., \& Srivastava, S. (1999). The Big-Five trait taxonomy: History, measurement, and theoretical perspectives. In L. A. Pervin \& O. P. John (Eds.), Handbook of personality: Theory and research (pp. 102-138). Guilford.

Kruglanski, A. W., Gelfand, M. J., Belanger, J. J., Shaveland, A., Hetiarachchi, M., \& Gunaratna, R. (2014). The psychology of radicalization and deradicalization: How significance quest impacts violent extrimism. Advance in Political Psychology, 35(1), 69-93. https:// doi.org/10.1111/pops.12163

Kruglanski, A. W., Pierro, A., Mannetti, L., \& De Grada, E. (2006). Groups as epistemic providers: need for closure and the unfolding of group-centrism. Psychological Review, 113(1), 84-100. https://doi.org/10.1037/0033295X.113.1.84

Kurniawan, W., Mujahid, D. R., \& Usman, Y. (2018). Apakah sastra mampu menurunkan cognitive closure pada narapidana terorisme di Indonesia? Jurnal Psikologi Sosial, 16(2), 114-124. https://doi.org/10.7454/jps.2018.11

Lakey, B., Orehek, E., Hain, K. L., \& Van Vleet, M. (2010). Enacted support's links to negative affect and perceived support are more consistent with theory when social influences are isolated from trait influences. Personality \& Social Psychology Bulletin, 36(1), 132-142. h t tp s://doi.org/10.1177/ 0146167209349375

Lounsbury, J. W., \& Gibson, L. W. (1998). Personal style inventory: A work-based personality measurement system. Resource Associates. 
Mandel, D. R. (2009). Radicalization: What does it mean. In T. M. et al. Pick (Ed.), Homegrown terrorism: Understanding and addressing the root causes of radicalisation among groups with an immigrant heritage in Europe (pp. 101113). IOS Press. https://doi.org/ 10.3233/978-1-60750-075-9-101

Milla, M. N. (2008). Bias heuristik dalam proses penilaian dan pengambilan strategi terorisme. Jurnal Psikologi Indonesia, 8(1), 10-21. http://jurnal.himpsi.or.id/ index.php/JPI/article/view/38

Milla, M. N., Faturochman, \& Ancok, D. (2012). The impact of leader-follower interactions on the radicalization of terrorists: A case study of the Balibombers. Asian Journal of Social Psychology, 16(2), 92-100. https:// doi.org/10.1111/ajsp.12007

Moghadam, A. (2006). The roots of terrorism. Infobase Publishing.

Moghaddam, F. M. (2005). The staircase to terrorism: A psychological exploration. In American Psychologist (Vol. 60, Issue 2, pp. 161-169). American Psychological Association. https://doi.org/10.1037/ 0003-066X.60.2.161

Moghaddam, F. M. \& Marsella, A. J. (2004). Understanding terrorism: Psychosocial roots, consequences, and interventions. American Psychological Association.

Muluk, H. (2016). Radikalisme dan terorisme dalam perspektif psikologi sosial. Universitas Indonesia. https:// www.ui.ac.id/berita/radikalisme-danterorisme-dalam-perspektif-psikologisosial.html

Nilsson, M. (2018). Jihadiship: From radical behavior to radical beliefs. Studies in Conflict \& Terrorism, 1-17. https:// d o i . o r g / 10 . 1080 / 1057610X.2018.1538092

Pervin, L. A., Cervone, D., \& Oliver, P. J. (2012). Psikologi kepribadian: Teori dan Penelitian (edisi ke-9). Kencana Prenada Media Group.
Piedmont, R. L., Bain, E., McCrae, R. R., Costa, P. T., \& Jr. (2002). The applicability of the five-factor model in a sub-saharan culture: The NEO-PI-R in Shona. In R. R. M. \& J. Allik (Ed), The Five-Factor Model of personality across cultures. Springer

PPIM UIN Jakarta. (2017). Survey PPIM/ : Transisi radikalisme agama. https:// ppim.uinjkt.ac.id/artikel/transmisiradikalisme-agama/

Pratama, D. A. (2012). Pengaruh kepribadian berdasarkan the big five personality terhadap kepuasan kerja karyawan hotel. Jurnal Gema Aktualita, 1(1), 57-67. http:/ /hdl.handle.net/123456789/42

Prior, A. (2016). Peran BNPT dalam pendidikan dan pencegahan tindak pidana terorism. UIN Syarif Haidayatullah Jakarta.

Putra, M. A. (2017). Survei Wahid Institute: 11 Juta orang mau bertindak radikal. CNN. https://www.cnnindonesia.com/ nasional/20170814172156-20 234701/survei-wahid-institute-11-jutaorang-mau

Roats, A. (2007). The need for closure concept disclosed: Delineating motivation from ability in human decision-making. University of Genk.

Roats, A., \& Van Heil, A. (2011). Item selection and validation of a brief, 15 -item version of the Need for Closure Scale. Personality and Individual Differences., 50(1), 90-94. h t tps://doi.org/10.1016/ j.paid.2010.09.004

Saifuddin. (2011). Radikalisme Islam di kalangan mahasiswa (Sebuah metamorfosa baru). Analisis, 9(1), 2832. https://doi.org/10.24042/ ajsk.v11i1.605

Satriawan, I., \& Lailam, T. (2019). Pencegahan gerakan radikalisme melalui penanaman ideologi pancasila dan budaya sadar konstitusi berbasis komunitas. Jurnal Surya Masyarakat, 1(2), 100-110. https:/ /jurnal.unimus.ac.id/index.php/JSM/ article/view/4460/4350 
Schlenger, W. E., Caddell, J. M., Ebert, L., Jordan, B. K., Rourke, K. M., Wilson, D., Thalji, L., Dennis, J. M., Fairbank, J. A., \& Kulka, R. A. (2002). Psychological reactions to terrorist attacks: findings from the National Study of Americans' Reactions to September 11. JAMA, 288(5), 581588. https://doi.org/10.1001/ jama.288.5.581

Schmid, A. P. (2013). Counter-radicalisation: $A$ conceptual discussion and literature review. Koningin Julianaplein.

Shah, J. Y., Kruglanski, A. W., \& Thompson, E. P. (1998). Membership has its (epistemic) rewards: Need for closure effects on ingroup bias. In Journal of Personality and Social Psychology (Vol. 75, Issue 2, pp. 383-393). American Psychological Association. https://doi.org/10.1037/ 0022-3514.75.2.383

Slootman, M., \& Tillie, J. (2006). Processes of Radicalisation. Why some Amsterdam Muslims become radicals. Institute for Migration and Ethnic Studies Universiteit van Amsterdam.

Smith, A. G. (2018). Risk factors and indicators associated with radicalization to terrorism in the United States: What research sponsored by the National Institute of Justice Tells Us. (pp. i-28). Department of Justice. https:// www.ncjrs.gov/pdffiles $1 / \mathrm{nij} /$ 251789.pdf

Talbot, R. W. J. (2008). The role of psychological processes in terrorism: Agroup-level analysis.
Taylor, S. E., Peplau, L. A., \& Sears, D. O. (2012). Psikologi sosial edisi kedua belas. Kencana Prenada Media Group.

Webber, D., Babush, M., Schori-Eyal, N., VazeouNieuwenhuis, A., Hettiarachchi, M., Bélanger, J. J., Moyano, M., Trujillo, H. M., Gunaratna, R., Kruglanski, A. W., \& Gelfand, M. J. (2018). The road to extremism: Field and experimental evidence that significance loss-induced need for closure fosters radicalization. Journal of Personality and Social Psychology, 114(2), 270-285. https:// doi.org/10.1037/pspi0000111

Webber, D. \& Kruglanski, A. W. (2018). The social psychological makings of a terrorist. Current Opinion in Psychology, 19, 131-134. https://doi.org/10.1016/ j.copsyc.2017.03.024

Webster, D. M., \& Kruglanski, A. W. (1994). Individual differences in need for cognitive closure. Journal of Personality and Social Psychology, 67(6), 1049-1062. https://doi.org/10.1037/00223514.67.6.1049

Weiner, E. A., \& Stewart, B. J. (1984). Assessing individuals: Psychological and educational tests and measurements. Little Brown.

Widhana, D. H. (2019). Bom Thamrin, teror yang disiapkan dari penjara. Tirto.Id. https://tirto.id/bom-thamrin-teroryang-disiapkan-dari-penjara-dedv

Received 23 January 2020 Revised9March 2020, 23 April 2020, 8June 2020 Accepted 16 June 2020 